\title{
Terminologia (antropocentryczna) - jej przedmiot badań i zadania poznawcze
}

\author{
(Anthropocentric) Terminology - its subject of study and cognitive tasks
}

\author{
Sambor GRUCZA \\ Uniwersytet Warszawski/ University of Warsaw \\ E-mail: sambor.grucza@uw.edu.pl,
}

\begin{abstract}
Many misunderstandings about what terminology does and what its cognitive tasks are, are a consequence of insufficiently precise treatment of the terms "term" and "terminology", and, consequently, incorrectly delineating the subject of study and cognitive tasks of terminology. The purpose of the considerations presented here is to try to organize these issues based on the main assumptions of anthropocentric linguistics (see F. Grucza 2012, S. Grucza 2013a, 2013b, 2017). In the first part of the paper a proposal to clarify the meaning of the term "term" will be presented, i.e. an attempt to answer the question about the ontological status of referred by the term "term". In the second part a proposal to clarify the meaning of the term "terminology" will be given, and in the third part a proposal of general description of the subject of the study and in the fourth part proposal of s description of cognitive tasks of terminology.
\end{abstract}

Keywords: term, idioterm, terminology, idioterminology, terminological competence, anthropocentric terminology

\section{Wstęp}

Wiele błędnych sposobów rozumienia tego, czym zajmuje się terminologia (nauka) i jakie są jej zadania poznawcze, jest konsekwencją niewystarczająco precyzyjnego traktowania wyrażeń ,termin” i ,terminologia”, a w konsekwencji błędnego zakreślania przedmiotu badań i zadań poznawczych terminologii (nauki). Celem przedstawionych tu rozważań jest próba uporządkowania tych kwestii w oparciu o główne założenia lingwistyki antropocentrycznej (zob. F. Grucza 2012, S. Grucza 2013a, 2013b, 2017).

W pierwszej części przedstawię propozycję uściślenia znaczenia wyrażenia ,termin", czyli próbę udzielenia odpowiedzi na pytanie, jaki jest status ontologiczny tego, do czego odnosi się wyrażenie ,termin”, jak istnieje to, co się tak nazywa oraz na pytanie, czym są, a czym nie są obiekty określane jako „terminy”. W drugiej części przedstawię propozycję uściślenia znaczenia wyrażenia ,terminologia”. W trzeciej części przedstawię propozycję opisu ogólnego przedmiotu, a w części czwartej propozycję opisu zadań poznawczych terminologii. 


\section{Rzeczywiste terminy i ich uogólnienia - idioterminy i politerminy}

Rozpocznijmy od wyrażenia ,termin”. W przyjętej optyce antropocentrycznej obiekty określane jako ,terminy” (czyli terminy), trzeba najpierw podzielić w zależności od tego, czy stanowią one pewne współczynniki (elementy) leksykalne konkretnych języków specjalistycznych konkretnych specjalistów, tj. czy stanowią one współczynniki idiolektów specjalistycznych, czy stanowią pewne elementy konkretnych tekstów specjalistycznych. Następnie trzeba zarówno jedne, jak i drugie odróżnić od terminów stanowiących elementy zewnętrznych leksykonów specjalistycznych reprezentujących albo sumę zbiorów terminów, albo iloczyn zbiorów terminów stanowiących albo współczynniki idiolektów specjalistycznych wziętych pod uwagę specjalistów, albo elementy konkretnych tekstów specjalistycznych.

W każdym razie z ontologicznego punktu widzenia czym innym są terminy rozważane jako składniki konkretnych idiolektów specjalistycznych i/lub konkretnych tekstów specjalistycznych, a czym innym terminy traktowane jako elementy takiego lub innego polilektu specjalistycznego i wreszcie zupełnie czym innym terminy traktowane jako elementy tego lub innego zbiorczego lub modelowego konstruktu lingwistycznego. Ostatecznie można dokonać następującej stratyfikacji sposobów ujmowania znaczenia wyrażenia ,termin”:

- idiotermin - współczynnik konkretnego idiolektu specjalistycznego konkretnego specjalisty;

- politermin - element zbioru reprezentującego sumę zbiorów lub iloczyn zbiorów idioterminów stanowiących współczynniki konkretnych idiolektów specjalistycznych wziętych pod uwagę specjalistów;

- termin wyrażenie - element konkretnego tekstu specjalistycznego, postać wyrażeniowa, konkretna realizacja substancjalna, obiekt eksternalizowany, czyli istniejący samodzielnie (w postaci fonicznej, graficznej, taktylnej, migowej);

- politermin wyrażenie - element zbioru reprezentującego sumę zbiorów lub iloczyn zbiorów terminów wyrażeń.

Powyższa stratyfikacja nie jest jednak domknięta, bowiem idiotermin, rozumiany jako współczynnik konkretnego idiolektu specjalistycznego, to albo określony zakres znaczeniowy, określony zakres wiedzy, pojęcie, albo struktura wyrażeniowa (fonematyczna, grafematyczna, taktylna, migowa), na podstawie której tworzona jest konkretna postać wyrażeniowa (dźwiękowa, graficzna, taktylna, migowa). W związku z tym wyróżnić trzeba:

- idiotermin pojęcie - współczynnik znaczeniowy konkretnego idiolektu specjalistycznego konkretnego specjalisty;

- idiotermin struktura wyrażeniowa - współczynnik strukturalny konkretnego idiolektu specjalistycznego konkretnego specjalisty, na podstawie której możliwa jest konkretna realizacja substancjalna terminu tekstu.

Dalszej stratyfikacji zakresu znaczeniowego trzeba dokonać także w odniesieniu do wyrażenia ,politermin”, może się on bowiem odnosić do:

- politermin pojęcie - element zbioru reprezentującego sumę zbiorów lub iloczyn 
zbiorów idioterminów pojęć stanowiących współczynniki konkretnych idiolektów specjalistycznych wziętych pod uwagę specjalistów;

- politermin struktura wyrażeniowa - element zbioru reprezentującego sumę zbiorów lub iloczyn zbiorów idioterminów struktur wyrażeniowych stanowiących współczynniki konkretnych idiolektów specjalistycznych wziętych pod uwagę specjalistów;

Z powyższych uwag wynika po pierwsze, że przyjęty tu zakres znaczeniowy wyrażenia ,idiolekt specjalistyczny” jest wyznaczony tak, że obejmuje on struktury wyrażeniowe powiązane ze znaczeniem i regułami komunikacyjnymi (pragmatycznymi) (S. Grucza 2013b). Ponieważ granice zbioru właściwości, który określa się jako „idiolekt", są względne, jego zakres można ograniczyć tak, że zbiór ten obejmie albo tylko struktury wyrażeniowe, albo struktury wyrażeniowe powiązane ze znaczeniem (F. Grucza 1983/2017: 330). Mówiąc inaczej, idiolekt można ująć albo jako plan wyrażeniowy, albo jako plan wyrażeniowy powiązany $\mathrm{z}$ planem treści (F. Grucza 2010/2017). Ja przyjmuję ich szerokie rozumienie włączające do zakresu rzeczywistości idiolektalnej plan wyrażeniowy i plan treści.

$\mathrm{Z}$ uwag tych wynika także, że czym innym jest struktura wyrażeniowa idioterminu (= idiotermin struktura wyrażeniowa), czyli obiekt/ fakt mentalny istniejący w mózgu konkretnego specjalisty jako pewien element jego wiedzy strukturalnej i operacjonalnej, a czym innym struktura konkretnego wyrażenia (= terminu wyrażenia).

Dyferencjacja zakresów rzeczywistości określonej powyżej jako idiotermin struktura wyrażeniowa $\mathrm{z}$ jednej strony i termin wyrażenie $\mathrm{z}$ drugiej strony, nawiązuje do rozróżnienia płaszczyzny rzeczywistości językowej oraz płaszczyzny rzeczywistości sygnałowej, jakiego F. Grucza dokonał w 1969 r. ${ }^{1}$ :

System językowy trzeba traktować jako płaszczyznę niezależną od płaszczyzny rzeczywistości sygnałowej już choćby $z$ tego powodu, że system językowy może zostać zrealizowany w postaci substancji różnego rodzaju. A także ponieważ w konkretnej komunikacji (w aktach mownych) systemu językowego w żadnej mierze nie zmieniają (nie naruszają) dokonywane w jej ramach (jej ciągu) transformacje implementującej go substancji (neurologicznej, fizjologicznej, akustycznej etc.). Ta stałość systemu językowego warunkuje w sposób zasadniczy skuteczność każdej komunikacji. To z tego powodu uważamy, że można zasadnie posługiwać się wyrażeniami typu ,system językowy leży u podłoża rzeczywistości sygnałowej” - że „funduje ją” (F. Grucza 2010/2017: 60).

W myśl tych rozróżnień zakres rzeczywistości wyznaczonej jako idiotermin struktura wyrażeniowa należy do płaszczyzny rzeczywistości językowej, a zakres wyznaczony jako termin wyrażenie do płaszczyzny rzeczywistości sygnałowej. $\mathrm{Z}$ tym, że dopowiedzieć trzeba, iż lingwistycznie dokonać można potrójnej (de)strukturyzacji językowej rzeczywistości sygnałowej:

\footnotetext{
${ }^{1}$ Pierwotnie przedstawionej w rozprawie habilitacyjnej zatytułowanej „Sprachliche Diakrise im Bereich der Ausdrucksebene des Deutschen“ (F. Grucza 1969), a przetłumaczonej na język polski w 2010 r. (zob. F. Grucza 2010/2017).
} 
Inaczej mówiąc: rzeczywistość sygnałową można poddać, i poddaje się, na poziomie rzeczywistości lingwistycznej trzem różnym rodzajom (de)strukturyzacji, w zależności od tego, który z trzech na-stępujących punktów widzenia zostanie wybrany w jej badaniu. Okazuje się bowiem, że konkretne sygnały (językowe) można segmentować, klasyfikować etc., czyli w skrócie - opisywać:

(1) jako niezależne wielkości fizykalne; na bazie danych uzyskanych w wyniku takiej analizy możemy skonstruować (między innymi) ich pewien model fonetyczny, lub inaczej mówiąc: pewien cząstkowy model rzeczywistości sygnałowej;

(2) jako wielkości zależne od reguł (konwencji) ich niesemantycznej interpretacji przez mówców-słuchaczy; w konsekwencji tego rodzaju analizy możemy skonstruować (wytworzyć) ich odpowiedni model fonologiczny;

(3) jako wielkości zależne od ich gramatyczno-semantycznej interpretacji przez mówców-słuchaczy; w rezultacie tej analizy możemy skonstruować ich odpowiedni model gramatyczny (F. Grucza 2010/2017: 74).

Tej kwestii nie będę tu dalej rozwijał.

$\mathrm{Z}$ powyższych uwag tych wynika także, że odrzucić trzeba wszelkie sformułowania typu ,termin to wyraz lub połączenie wyrazowe”, „termin to nazwa pojęcia”, „spójny zbiór pojęć", „termin to podstawowy środek wyrażania i wymiany myśli”" (por. J. Tomaszczyk 2017), „termin to zespolenie substratu językowego z superstratem logicznym” (W. Lejczyk/ L. Biesiekirska 1998), ,termin to znak językowy oznaczający pojęcie (J. Lukszyn/ W. Zmarzer 2001), bowiem wypaczają one poznawczy ogląd rzeczywistości terminologicznej.

Wynika z nich także to, że wyróżnić można kompetencję w zakresie języka specjalistycznego, tj. specjalistyczną kompetencję językową i kompetencję terminologiczną. Do zakresu tej pierwszej zaliczyć można (ujmując jej zakres najszerzej) struktury wyrażeniowe powiązane ze znaczeniem i regułami komunikacyjnymi (pragmatycznymi) i umiejętności posługiwania się nimi. Natomiast do kompetencji terminologicznej zaliczyć można umiejętności wyznaczania zakresów znaczeniowych, zakresów pojęć, czyli określania zakresów idioterminów pojęć oraz umiejętności tworzenia nowych struktur wyrażeniowych, za pomocą których te idioterminy pojęcia mogą być substancjalnie nazywane. Moim zdaniem, do zakresu kompetencji terminologicznej włączyć trzeba także część kompetencji epistemologicznej, kognitywnej, na podstawie której możliwe jest tworzenie nowej wiedzy, nowych pojęć, mentalnego przetwarzania świata (zob. w tej sprawie także A. Bajerowska 2017, 2018, A. Sztuk 2018).

\section{Rzeczywiste terminologie i ich uogólnienia - idioterminologie i politerminologie}

Uściślenia wymagają także sposoby dotychczasowego posługiwania się wyrażeniem „terminologia” w rozumieniu zbioru terminów. W świetle powyższych uwag obiekty określane jako „terminologie” trzeba najpierw podzielić, w zależności od tego, czy traktuje się je jako zbiory elementów leksykalnych, uznanych za terminy i składających się na konkretne języki specjalistyczne konkretnych specjalistów, tj. kompo- 
nenty terminologiczne idiolektów specjalistycznych), czy jako zewnętrzne zbiory odpowiednich jednostek leksykalnych, czyli zbiory „,reprezentujące” albo sumy zbiorów, albo iloczyny zbiorów konkretnych komponentów terminologicznych idiolektów specjalistycznych wziętych pod uwagę specjalistów, tj. jako słowniki/ tezaurusy terminologiczne.

Oznacza to, że obiekty, do których odnosi się wyrażenie „terminologia” trzeba podzielić na trzy kategorie:

- idioterminologia - skład idioterminów konkretnego specjalisty, czyli konkretny komponent terminologiczny konkretnego idiolektu specjalistycznego konkretnego specjalisty;

- idioterminologia pojęcia - skład idioterminów pojęć konkretnego specjalisty, czyli współczynniki znaczeniowe konkretnego idiolektu specjalistycznego konkretnego specjalisty;

- idioterminologia struktury wyrażeniowej - współczynniki strukturalne idiolektu specjalistycznego konkretnego specjalisty, na podstawie których możliwa jest konkretna realizacja substancjalna terminu tekstu;

- politerminologia - element zbioru reprezentującego sumę zbiorów lub iloczyn zbiorów idioterminologii stanowiących współczynniki konkretnych idiolektów specjalistycznych wziętych pod uwagę konkretnych specjalistów;

- politerminologia pojęcia - element zbioru reprezentującego sumę zbiorów lub iloczyn zbiorów idioterminologii pojęć wziętych pod uwagę specjalistów;

- idioterminologia struktury wyrażeniowej - element zbioru reprezentującego sumę zbiorów lub iloczyn zbiorów idioterminologii struktur wyrażeniowych wziętych pod uwagę specjalistów;

- terminologia wyrażenia - zbiór postaci wyrażeniowych, konkretnych realizacji substancjalnych, obiektów eksternalizowanych, czyli istniejący samodzielnie (w postaci fonicznej, graficznej, taktylnej, migowej);

- politerminologia wyrażeń - element zbioru reprezentującego sumę zbiorów lub iloczyn zbiorów stanowiących terminologie wyrażenia konkretnych realizacji substancjalnych wziętych pod uwagę.

Zgodnie z uwagami poczynionymi wcześniej zakres rzeczywistości wyznaczonej jako idioterminologia struktury wyrażeniowej należy do płaszczyzny rzeczywistości językowej, a zakres wyznaczony jako terminologia wyrażenia do płaszczyzny rzeczywistości sygnałowej. I także w odniesieniu do tej ostatniej można lingwistycznie dokonać potrójnej (de)strukturyzacji językowej rzeczywistości sygnałowej.

\section{Konkretny i uogólniony przedmiot terminologii}

Zacznijmy od stwierdzenia, że z teleologicznego punktu widzenia trzeba oddzielić od siebie praktyczne i poznawcze zajmowanie się terminami. W obrębie poznawczego zajmowania się terminami można wyróżnić między innymi przednaukowe, naukowe, hobbystyczne, profesjonalne zajmowanie się terminami. Jak słusznie zauważył F. Grucza (1991/2017) praktycznego zajmowania się terminami nie można nazywać „terminologią (nauką)”. Pozostając w zgodzie z paradygmatycznie zdeterminowaną 
predyspozycją znaczeniową wyrażenia ,terminologia”, ograniczam jego funkcję semantyczną do zakresu naukowego zajmowania się terminami.

Chcąc dokładnie opisać (wyróżnić) przedmiot terminologii trzeba, podobnie jak w przypadku przedmiotu jakiejkolwiek innej empirycznej dziedziny nauki, ustalić najpierw konstytuujące go obiekty, następnie właściwości, z uwagi na które terminologia interesuje się obiektami wziętymi pod uwagę oraz relacje pomiędzy tymi właściwościami, czyli pomiędzy obiektami wziętymi pod uwagę.

Jeśli dowolnemu specjaliście przypisze się indykator $\mathrm{S}$, to ich zbiór konstytuujący prymarny przedmiot terminologii można zapisać następująco:

$$
\left\{\mathrm{S}_{1} \ldots, \mathrm{S}_{\mathrm{X}}\right\}
$$

Przypisując z kolei dowolnej właściwości językowej uznanej za element terminologii danego specjalisty indykator W(JS) można zbiór właściwości wszystkich wziętych pod uwagę właściwości specjalistów $S_{1} \ldots S_{X}$, którymi interesuję się terminologia, przedstawić następująco:

$$
\left\{\mathrm{W}(\mathrm{T})_{1} \ldots, \mathrm{W}(\mathrm{T})_{\mathrm{y}}\right\}
$$

Następnie, jeżeli dowolnej relacji pomiędzy branymi pod uwagę właściwościami $\mathrm{W}(\mathrm{T})_{1} \ldots \mathrm{W}(\mathrm{T})_{\mathrm{y}}$ wyróżnionych specjalistów przypiszemy indykator $\mathrm{R}(\mathrm{WT})$, to zbiór relacji interesujących terminologie można przedstawić tak:

$$
\left\{\mathrm{R}(\mathrm{WT})_{1} \ldots, \mathrm{R}(\mathrm{WT})_{\mathrm{z}}\right\}
$$

Ogólną postać przedmiotu terminologii można zatem zdefiniować następująco:

$$
\left\{\mathrm{S}_{1} \ldots, \mathrm{S}_{\mathrm{x}} ; \mathrm{W}(\mathrm{T})_{1} \ldots, \mathrm{W}(\mathrm{T})_{\mathrm{y}} ; \mathrm{R}(\mathrm{WT})_{1} \ldots, \mathrm{R}(\mathrm{WT})_{\mathrm{z}}\right\}
$$

Powyższe uwagi wymagają następujących uściśleń.

Po pierwsze, definicja przedmiotu terminologii nie opisuje żadnego konkretnego przedmiotu terminologii, lecz odzwierciedla pewną uogólnioną postać konkretnych przedmiotów terminologii - ich pewną idealizację. Koniecznym staje się zatem rozróżnienie terminologii ogólnej (supralingwalnej) - zajmującej się terminami w wymiarze ponadposzczególnojęzykowym, czyli terminami w ogóle, terminologię poszczególnojęzykową (monolingwalną), zajmującą się terminami w obrębie konkretnego języka (polskiego, niemieckiego itd.), oraz terminologię dyscyplinową, zajmującą się terminami w obrębie konkretnego (dziedzinowego) języka specjalistycznego (por. F. Grucza 1991/2017).

Po drugie, wzięci pod uwagę specjaliści interesują terminologię o tyle, o ile potrafią tworzyć i nadawać i odbierać terminy oraz posługiwać się nimi zarówno w komunikacji specjalistycznej, jak i specjalistycznym poznaniu (tworzeniu wiedzy specjalistycznej). Inaczej mówiąc konkretne osoby zalicza się do zbioru konstytuującego przedmiot terminologii z uwagi na te ich właściwości, które określa się jako ich terminologiczne właściwości językowe. Można też powiedzieć, że konkretne osoby zalicza się do zbioru konstytuującego przedmiot terminologii z uwagi na ich specjalistyczne kompetencje językowe i/ lub kompetencje terminologiczne.

Po trzecie, terminologia musi z natury rzeczy zacząć swoje badania od rekonstrukcji idioterminów (idioterminologii), czyli od rekonstrukcji elementów komponentu terminologicznego konkretnego języka specjalistycznego konkretnego specjalisty zarówno na płaszczyźnie rzeczywistości językowej, jak i na płaszczyźnie rzeczywistości 
sygnałowej. Rekonstrukcja taka możliwa jest jedynie w drodze ekscerpcji i analizy terminów konkretnych tekstów specjalistycznych, czyli terminów wyrażeń. Jest tak, ponieważ żaden rzeczywisty termin, idiotemin, podobnie jak żaden idolekt, nie jest dostępny żadnej bezpośredniej obserwacji empirycznej. Poznanie jakiegokolwiek idioteminu możliwe jest jedynie poprzez obserwację i analizę zachowań oraz wytworów (rezultatów) określonych operacji (językowych) jego posiadacza, czyli konkretnego specjalisty, w szczególności poprzez analizę (a) wytworzonych (wytwarzanych) przez niego tekstów specjalistycznych oraz (b) sposobów posługiwania się nimi.

Po czwarte, w rzeczywistości nie ma specjalistów w ogóle - faktycznie istnieją tylko specjaliści będący specjalistami w jakimś konkretnym zakresie. Oznacza to, że faktycznie terminologia jest najpierw terminologią zajmującą się jakimś konkretnym komponentem terminologicznym konkretnego języka specjalistycznego konkretnej osoby reprezentującej jakąś konkretną wspólnotę specjalistyczną. Trzeba zatem przyjąć, że realnie jest wiele przedmiotów terminologii - tyle, ile specjalizacji wyodrębniono w ramach danej wspólnoty językowej.

\section{Zadania terminologii}

Zadaniem każdej nauki, a zatem także terminologii, jest pozyskanie wiedzy naukowej. W ujęciu teleologicznym w obrębie wiedzy naukowej można wyróżnić wiedzę w zależności od tego, czy dotyczy ona przedmiotów, które (a) istnieją, (b) istniały, bądź (c) będą istnieć. W konsekwencji takiego podziału można wyróżnić (a) wiedzę diagnostyczną, czyli wiedzę dotyczącą stanów rzeczy w obrębie danego przedmiotu poznania, co do których zakłada się, że istnieją, (b) wiedzę anagnostyczną, czyli wiedzę dotyczącą rekonstrukcji i/lub komparacji stanów rzeczy, co do których zakłada się, że istniały, (c) wiedzę prognostyczną, czyli wiedzę dotyczącą stanów rzeczy w obrębie danego przedmiotu poznania, co do których zakłada się, że będą istnieć w przyszłości. W obrębie tej ostatniej wyróżnić trzeba wiedzę dotyczącą (ca) stanów rzeczy, co do których zakłada się, że zaistnieją jako następniki stanów rzeczy aktualnie stwierdzonych, (cb) wiedzę dotyczącą tego, jak zachowają się dane stany rzeczy, jeśli poddane zostaną określonym oddziaływaniom człowieka, (cc) wiedzę dotyczącą urzeczywistniania nowych stanów rzeczy, co do których zakłada się, że jeszcze nie istnieją.

Przenosząc powyższe uściślenia na grunt terminologii, relacje hierarchiczne, jakie zachodzą pomiędzy terminologiczną wiedzą anagnostyczną, diagnostyczną i prognostyczną można przedstawić graficznie w następujący sposób (por. F. Grucza 1983/2017: 77):

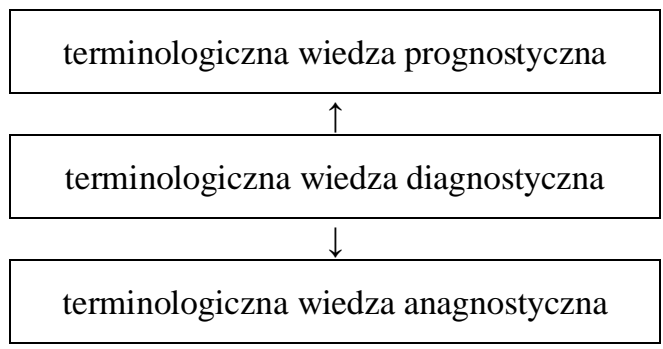

Schemat 1. Relacje hierarchiczne między terminologiczna wiedza diagnostyczna, anagnostyczna i prognostyczna (za F. Grucza 1983/2017: 67). 
Centralnym, podstawowym członem tak wyróżnionej wiedzy specjalistycznej jest wiedza diagnostyczna, gdyż stanowi ona podstawę derywacyjną zarówno dla wiedzy anagnostycznej, jak i prognostycznej. Ale wiedza agnostyczna stanowi w pewnym sensie uzupełnienie wiedzy diagnostycznej, gdyż ,dostarcza jak gdyby genetycznej eksplikacji ustaleń diagnostycznych”. Natomiast wiedzę prognostyczną można z jednej strony traktować jako swoistą kontynuację progresywnej (przebiegającej zgodnie z wektorem czasu) perspektywy anagnostycznej, z drugiej strony jako swoiste poprzedzenie regresywnej perspektywy anagnostycznej" (F. Grucza 1983: 74)².

Ostatecznie zadania teleologiczne terminologii można przedstawić tak:

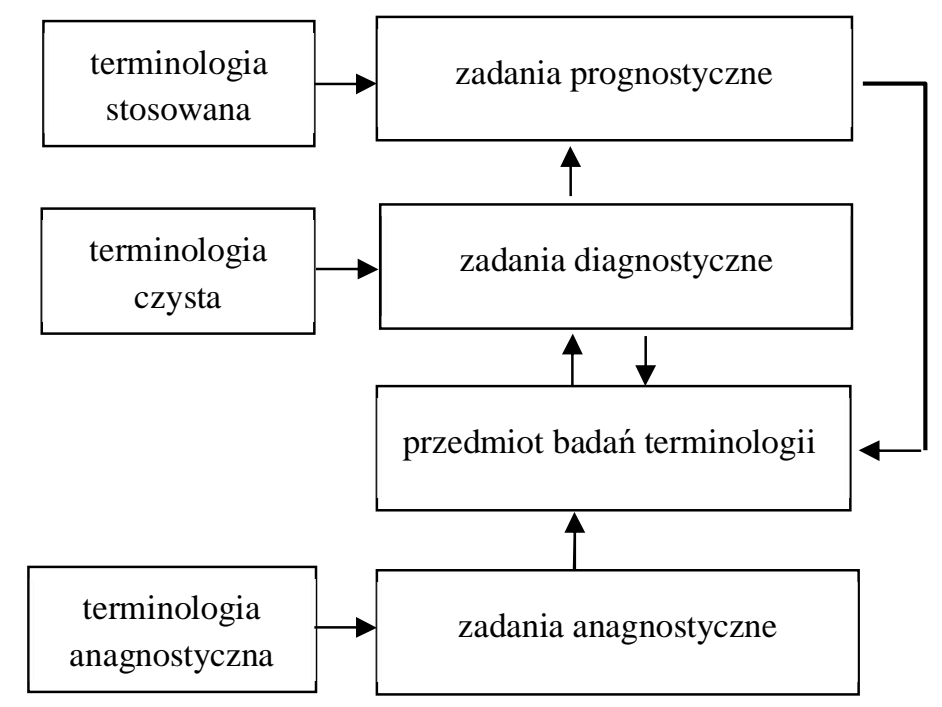

Rysunek 1. Relacje hierarchiczne między zadaniami terminologii.

Najważniejszym zadaniem diagnostycznej terminologii jest bowiem pozyskanie wiedzy dotyczącej aktualnego stanu rzeczywistości wyróżnionej jako „termin”/,terminologie". Natomiast najistotniejszym zadaniem stosowanej terminologii jest udzielenie odpowiedzi na odnośne pytania natury aplikatywnej, czyli na pytania o możliwości udoskonalenia badanych terminów i umiejętności posługiwania się nimi, a także na pytanie o możliwości usprawnienia specjalistycznych dyskursów, tzn. posługiwania się terminami

\subsection{Terminologia czysta - zadania diagnostyczne}

Inicjalne badania diagnostyczne terminologii, czyli badania, od których terminologia

${ }^{2}$ Specjalistyczną wiedzę diagnostyczną, anagnostyczną i prognostyczną można jeszcze podzielić według kilku dalszych kryteriów. Nie będę tu jednak referował - zainteresowanych odsyłam do pracy F. Gruczy ,Zagadnienia metalingwistyki. Lingwistyka - jej przedmiot, lingwistyka stosowana" (1983/2017: 55 i nast.), w której zostały one przedstawione w szczegółach. 
musi rozpocząć, to naukowa obserwacja obiektów konstytuujących jej przedmiot, czyli specjalistów oraz analiza wytworzonego przez nich materiału, czyli wytworzonych przez nich tekstów specjalistycznych. Następną fazę tego członu terminologii stanowi praca mająca na celu rekonstrukcję tych właściwości obserwowanych specjalistów, na bazie których tworzą oni teksty specjalistyczne, czyli komponentów terminologicznych ich języków specjalistycznych. Dodajmy od razu, że o opisie można mówić w tym przypadku tylko w odniesieniu do materiału, czyli do tekstów specjalistycznych, a nie w odniesieniu do właściwości ich twórców, czyli komponentów terminologicznych ich języków specjalistycznych. Rezultaty terminologicznej rekonstrukcji tych ostatnich, to $\mathrm{w}$ gruncie rzeczy pewne teorie - modele terminologiczne/lingwistyczne. W konsekwencji zadania diagnostyczne terminologii trzeba podzielić na dwie fazy - deskryptywną (opisową) i eksplikatywną (teoretyczną sensu stricto).

Ze stwierdzenia, iż głównym zadaniem terminologii jest rekonstrukcja składów terminologicznych języków specjalistycznych, na podstawie których badane teksty zostały wytworzone, czyli rekonstrukcja idioltermiologii ${ }^{3}$ ich twórców wynika, że do terminologii należy zarazem ustalenie, czy lub w jakim stopniu (z)rekonstruowane idioterminologie są rzeczywiście specjalistyczne, tzn. czy lub w jakiej mierze różnią się one od komponentu leksykalnego idiolektu podstawowego wziętych pod uwagę specjalistów, a czym od komponentów terminologicznych idiolektów specjalistycznych osób reprezentujących inne specjalizacje (zawody), funkcjonujące w obrębie danej wspólnoty językowej. Ale terminologia może i powinna zająć się ustaleniem nie tylko odmienności, lecz także jakości rekonstruowanych komponentów terminologicznych - najpierw komponentów terminologicznych odpowiednich idiolektów specjalistycznych, a następnie komponentów terminologicznych odpowiednich polilektów specjalistycznych.

Zarówno odmienność, jak i jakość badanych komponentów terminologicznych ma oczywiście z natury rzeczy charakter komparatywny. Wynika z tego, że zadania terminologii trzeba podzielić na zadania rekonstrukcyjne (,opisowe”) oraz komparatywne. Inaczej mówiąc do zadań terminologii poza rekonstrukcją języków specjalistycznych włączyć trzeba także ich porównywanie. Terminologia może porównywać (a) poszczególne idioterminologie - zarówno specjalistów tej samej dziedziny, jak i specjalistów różnych dziedzin, (b) różne politerminologie (różnych zbiorów specjalistów) w obrębie tej samej wspólnoty specjalistycznej, (c) różne polilterminologie różnych wspólnot specjalistycznych. W przypadku ostatnim może ona porównywać albo (ca) polilterminologie różnych wspólnot specjalistycznych, funkcjonujących w obrębie tej samej ogólnej wspólnoty językowej, albo (cb) politerminologie różnych dziedzin specjalistycznych funkcjonujących $\mathrm{w}$ obrębie dwóch lub więcej różnych ogólnych wspólnot językowych (F. Grucza 1991/2017).

Zadanie terminologii nie kończy się zatem na rekonstrukcji poszczególnych idioterminologii. Jej zdaniem jest, rzecz jasna, także rekonstrukcja polilterminologii ba-

\footnotetext{
${ }^{3}$ Zarówno idioterminologii pojęcia, jak i idioterminologii struktury wyrażeniowej.
} 
danej wspólnoty specjalistycznej zarówno rozumianych jako suma zbiorów, bądź iloczyn zbiorów terminologii wziętych pod uwagę specjalistów. Oznacza to, że terminologia zajmująca się badaniem komponentów terminologicznych danej wspólnoty specjalistycznej musi zakres swojego przedmiotu poszerzać tak, aby ostatecznie wziąć pod uwagę właściwości terminologiczne wszystkich specjalistów stanowiących tę wspólnotę. Trzeba zatem przyjąć, że można wyróżnić wiele polilterminologii w zależności od tego, specjalistów jakich specjalności weźmie się pod uwagę oraz w zależności od tego ilu specjalistów weźmie się pod uwagę.

Do zdań terminologii czystej należy także rekonstrukcja współczynnika terminologicznego specjalistycznej kompetencji językowej, czyli umiejętności posługiwania się terminami wyrażeniami w komunikacji specjalistycznej w celu transferencji wiedzy specjalistycznej oraz rekonstrukcja kompetencji terminologicznej, tj. umiejętności wyznaczania zakresów znaczeniowych, zakresów pojęć, czyli określania zakresów idioterminów pojęć oraz umiejętności tworzenia struktur wyrażeniowych, za pomocą których te idioterminy pojęcia są nazywane.

\subsection{Terminologia stosowana - zadania prognostyczne}

Podsumowując poczynione w poprzedniej części uwagi można powiedzieć, że zadaniem czystej terminologii - ogólnie rzecz ujmując - jest udzielenie odpowiedzi, po pierwsze na pytanie o aktualny stan rzeczywistości wyróżnionej jako komponent terminologiczny lub komponenty terminologiczne - tzn. na pytanie o skład i substancjalną, a także funkcjonalną odmienność tej rzeczywistości oraz, po drugie, na dotyczące tej rzeczywistości pytania porównawcze. W żadnym jednak razie zadania terminologii nie kończą się ani na zrekonstruowaniu interesujących ją komponentów terminologicznych, ani na ich porównaniu. Do jej zadań należy także zajęcie się przeszłością (historią) i przyszłością (rozwojem) badań terminologicznych.

Zadaniem terminologii prognostycznej, zgodnie z modelem nauki przyjętym za podstawę niniejszych rozważań, jest udzielenie najpierw odpowiedzi na pytanie o „,naturalny” rozwój badanych komponentów terminologicznych, tzn. o ich rozwój dokonujący się bez jakiejkolwiek ingerencji zewnętrznej. Jednakże, z punktu widzenia pozalingwistycznych potrzeb praktycznych, za najważniejsze pytanie, na jakie musi odpowiedzieć terminologia prognostyczna, uznać trzeba pytanie o możliwości racjonalnego ingerowania w ich rozwój w celu doskonalenia tak badanych komponentów terminologicznych, jak i umiejętności posługiwania się nimi, a także pytanie o możliwości usprawnienia specjalistycznej komunikacji, czyli posługiwania się tekstami specjalistycznymi. Dotyczy to mianowicie takiego udoskonalenia komponentów terminologicznych języków specjalistycznych, które umożliwiłoby posługującym się nimi specjalistom spełnienie w możliwie jak najlepszy sposób ich potrzeb i zadań zarówno kognitywnych, jak i komunikacyjnych. Chodzi tu zatem o zmiany umożliwiające im lepiej niż dotychczas pozyskiwać, przetwarzać czy porządkować wiedzę specjalistyczną i/lub porozumiewać się w sprawach specjalistycznych. Ogniwo terminologii, które powinno zając się tymi zagadnieniami, to terminologia stosowana. 
Do zadań terminologii stosowanej należy także „ulepszanie” współczynnika terminologicznego specjalistycznej kompetencji językowej, czyli umiejętności posługiwania się terminami wyrażeniami w komunikacji specjalistycznej w celu transferencji wiedzy specjalistycznej oraz ,ulepszanie” kompetencji terminologicznej, tj. umiejętności wyznaczania zakresów znaczeniowych, zakresów pojęć, czyli określania zakresów idioterminów pojęć oraz umiejętności tworzenia struktur wyrażeniowych, za pomocą których te idioterminy pojęcia są nazywane.

\section{Uwagi końcowe}

Ponieważ przedstawiona powyżej koncepcja terminologii (nauki) opiera się na głównych założeniach lingwistyki antropocentrycznej, koncepcję tę można nazwać terminologią antropocentryczną ${ }^{4}$. Jednak bez względu na to, jak ją nazwiemy, terminologii (nauki) nie można określić mianem ,,nauki interdyscyplinarnej”, jak to ujęła J. Mazurkiewicz-Sułkowska (2013: 123), nie można także powiedzieć, że funkcjonuje „na pograniczu językoznawstwa, logiki, teorii informacji, leksykografii, semiotyki i nauk empirycznych" (ibid).

W pierwszej kwestii powiem tylko, że terminologia nie jest nauką interdyscyplinarną, ponieważ, jak wykazałem, można jednoznacznie określić jej specyficzny przedmiot badań. W pełni podzielam pogląd, że:

[...] pierwotnym elementem konstytutywnym poszczególnej nauki jest właśnie jej przedmiot. Od niego, od jego istoty, zależne są wszystkie inne jej elementy, w tym także jej metody i narzędzia poznania. Poszczególne nauki różnią się między sobą najpierw swymi przedmiotami. Przedmioty te mogą się z kolei różnić między sobą bądź zaliczonymi do ich składu fragmentami uniwersum, czyli ze względu na obiekty zaliczone do zbioru $\mathrm{U}^{5}$ bądź też - o ile odnoszą się do tych samych fragmentów uniwersum - zbiorami właściwości $\mathrm{F}_{\mathrm{l}} \mathrm{y}$.., $\mathrm{Fn}^{6}{ }^{6}$ wyróżnionych w U obiektów, lub zbiorami zależności $\mathrm{f}_{\mathrm{l}} \mathrm{y} . ., \mathrm{fm}^{7}$ między owymi właściwościami, bądź wreszcie wszystkim. Na specjalne podkreślenie zasługuje przede wszystkim fakt, że ten sam zbiór obiektów może stanowić podstawę przedmiotów różnych dziedzin. Dwie, a nawet więcej różnych nauk może się bowiem interesować tym samym zbiorem obiektów $\mathrm{U}$, ale ze względu na ich całkiem różne właściwości czy funkcje. Przedmiotu nauki nie należy zatem automatycznie identyfikować ze zbiorem danych obiektów (F. Grucza 1983/2017: 21).

Co się tyczy stwierdzenia, że terminologia „funkcjonuje” na takim, czy innym pograniczu, to powiem tylko, iż zdaje się, że ci, którzy tak twierdzą nie dostrzegają, że czym innym jest płaszczyzna podmiotu badań (terminologii), a czym innym płaszczyzna

\footnotetext{
${ }^{4}$ Przegląd innych koncepcji terminologicznych przedstawiony został w M. Małachowicz/ S. Grucza 2017.

${ }^{5} \mathrm{~W}$ przedstawionym powyżej modelu $\left\{\mathrm{S}_{1} \ldots, \mathrm{S}_{\mathrm{X}}\right\}$.

${ }^{6} \mathrm{~W}$ przedstawionym powyżej modelu $\left\{\mathrm{W}(\mathrm{T})_{1} \ldots, \mathrm{W}(\mathrm{T})_{\mathrm{y}}\right\}$.

${ }^{7} \mathrm{~W}$ przedstawionym powyżej modelu $\left\{\mathrm{R}(\mathrm{WT})_{1} \ldots, \mathrm{R}(\mathrm{WT})_{\mathrm{Z}}\right\}$.
} 
metod badawczych (terminologii). Kwestii tej nie będę tu dalej rozwijał. Wyczerpujące uwagi tej w sprawie przedstawił już F. Grucza (1983/2017).

\section{Bibliografia}

Bajerowska, A. (2017), Wiedze specjalistyczne - terminy - ontologie terminologiczne, (w:) M. Małachowicz/ S. Grucza (red.), Polskie i europejskie nurty terminologiczne. Warszawa, 68-88. (URL http://sn.iksi.uw.edu.pl/wp-content/uploads/sites/306/2018/09/SN-38-M.-Ma\%C5\%82achowicz-S.Grucza-Polskie-i-europejskie-nurty-terminologiczne.pdf). [Pobrano 15.03.2020].

Bajerowska, A. (2018), Inkorporowanie modeli z dziedziny fizyki, matematyki i neurobiologii na grunt lingwistyki antropocentrycznej, (w:) „Applied Linguistics Papers" $25 / 1,1-8$.

Grucza, F. (1969/2017), Sprachliche Diakrise im Bereich der Ausdrucksebene des Deutschen. Poznań. [także jako: Franciszek Grucza. Dzieła zebrane, t. 11, (red.) S. Grucza/ M. Olpińska-Szkiełko/ M. Płużyczka/ I. Banasiak/ M. Łączek/ A. Bonek/ A. Kaleta/ A. Sztuk. Warszawa, 2017. (URL http://www.iksi.uw.edu.pl/documents/11738337/14640936/FG_Tom_11.pdf). [Pobrano 15.03.2020]].

Grucza, F. (1983/2017), Zagadnienia metalingwistyki. Lingwistyka - jej przedmiot, lingwistyka stosowana. Warszawa. [także jako: Franciszek Grucza. Dzieta zebrane, t. 8, (red.), S. Grucza/ M. Olpińska-Szkiełko/ M. Płużyczka/ I. Banasiak/ M. Łączek/ A. Bonek/ A. Kaleta/ A. Sztuk. Warszawa, 2017. (URL http://www.iksi.uw.edu.pl/documents/11738337/14640936/FG_Tom_8.pdf). [Pobrano 15.03.2020]].

Grucza, F. (1991/2017), Terminologia - jej przedmiot, status i znaczenie, (w:) F. Grucza (red.), Teoretyczne podstawy terminologii. Wrocław/Warszawa/Kraków, 1144. [także w: Franciszek Grucza, Dzieła zebrane, t. 3, (red.) S. Grucza/ M. Olpińska-Szkiełko/ M. Płużyczka/ I. Banasiak/ M. Łączek/ A. Bonek/ A. Kaleta/ A. Sztuk. Warszawa, 2017. (URL http://www.iksi.uw.edu.pl/documents/11738337/14640936/FG_Tom_3.pdf). [Pobrano 15.03.2020]].

Grucza, F. (2010/2017), Stratyfikacyjny model budowy i diakryzy języków ludzkich. Warszawa. [także jako: Franciszek Grucza, Dzieła zebrane, t. 11, (red.) S. Grucza/ M. Olpińska-Szkiełko/ M. Płużyczka/ I. Banasiak/ M. Łączek/ A. Bonek/ A. Kaleta/ A. Sztuk. Warszawa, 2017. (URL http://www.iksi.uw.edu.pl/documents/11738337/14640936/FG_Tom_11.pdf). [Pobrano 15.03.2020].

Grucza, F. (2012), Antropocentryczna a paradygmatyczna (tradycyjna) lingwistyka (stosowana) i kulturologia (stosowana), (w:) „Lingwistyka Stosowana/ Applied Linguistics/ Angewandte Linguistik" 6, 5-43. (URL http://alp.uw.edu.pl/wp-content/uploads/sites/315/2018/03/Lingwistyka-Stosowana-6_2012.pdf). [Pobrano 15.03.2020].

Grucza, S. (2013a), Od lingwistyki tekstu do lingwistyki tekstu specjalistycznego. Warszawa, wyd. 3. (URL http://portal.uw.edu.pl/web/snikla/tomy-serii). [Pobrano 15.03.2020]. 
Grucza, S. (2013b), Lingwistyka języków specjalistycznych. Warszawa, wyd. 2. (URL https://portal.uw.edu.pl/web/snikla/tomy-serii). [Pobrano 15.03.2020].

Grucza, S. (2017), Lingwistyka antropocentryczna, (w:) Franciszek Grucza, Dzieta zebrane, t. 1: O nauce prof. Franciszka Gruczy, (red.) S. Grucza/ M. OlpińskaSzkiełko/ M. Płużyczka/ I. Banasiak/ M. Łączek/ A. Bonek/ A. Kaleta/ A. Sztuk. Warszawa, 161-180. (URL http://www.iksi.uw.edu.pl/documents/11738337/14640936/FG_Tom_1.pdf). [Pobrano 15.03.2020].

Lejczyk, W./ L. Biesiekirska (1998), Terminoznawstwo: przedmiot, metody, struktura. Białystok.

Lukszyn, J./ W. Zmarzer (2001), Teoretyczne podstawy terminologii. Warszawa

Małachowicz, M./ S. Grucza (red.) (2017), Polskie i europejskie nurty terminologiczne. Warszawa. (URL http://sn.iksi.uw.edu.pl/wp-content/uploads/sites/306/2018/09/SN-38-M.-Ma\%C5\%82achowicz-S.Grucza-Polskie-i-europejskie-nurty-terminologiczne.pdf). [Pobrano 15.03.2020].

Mazurkiewicz-Sułkowska, J. (2013), Uwagi dotyczace wspótczesnej terminologii technicznej $w$ języku polskim, rosyjskim i bułgarskim (na przykładzie terminów z branży cukrowniczej), (w:) „Rozprawy Komisji Językowej ŁTN” 59, 123-133.

Sztuk, A. (2018), Terminologische Kompetenz. Zur Eingrenzung des Entitäten- und Forschungsbereichs, (w:) M. Sitek (red.), Schlüsselkompetenz Fachsprache. Zwischen Theorie und Anwendung. Frankfurt/M., 165-177.

Tomaszczyk, J. (2017), Terminologia w komunikacji naukowej, (w:) A. Pulikowski (red.), Kultura książki i informacji: księga jubileuszowa dedykowana Profesor Elżbiecie Gondek. Katowice, 383-393. (URL https://rebus.us.edu.pl/handle/20.500.12128/8568). [Pobrano 15.03.2020]. 